\title{
Habitat use and management for the Noisy Scrub-bird Atrichornis clamosus
}

\author{
G. T. SMITH
}

\section{Summary}

After European settlement, the range of the Noisy Scrub-bird Atrichornis clamosus contracted and only the population at Two Peoples Bay survived. Management policy at Two Peoples Bay Nature Reserve has been one of wildfire prevention, which has created increased areas of suitable habitat for the species. Territories rose from 45 in 1970 to 189 in 1994. Habitat use was assessed by grouping the dominant vegetation associations in each territory in five categories, in descending order of suitability (assessed on breeding and feeding resources): low eucalypt forest, Agonis forest, tall thicket, low thicket and heath. Turnover rates in territory use gave the same habitat rankings. A range of values of $N_{\mathrm{e}}$ (effective population size) was calculated using assumptions about breeding potential of each habitat category. There may be insufficient habitat at Two Peoples Bay for the population to reach an $N_{\mathrm{e}}$ of 500 . Successful translocation to Mt Manypeaks, and the establishment of three small populations by birds dispersing from Two Peoples Bay, suggest that an integrated regional population can develop with an $N_{\mathrm{e}}$ well in excess of 500. The management of areas with populations and the corridors linking them must include minimizing the incidence and extent of wildfires.

\section{Introduction}

The establishment of a nature reserve for an endangered species is usually the final episode in a long political process (e.g. Chatfield in press). While this may be the end-product for legislators, for those agencies charged with the responsibility of managing the reserve it is merely the start of an even longer process aimed at ensuring the survival of the species.

The increasingly fragmented landscapes within which conservationists have to work provide little opportunity to design a reserve, or system of reserves, which will provide the resources to enable a species to survive with little or no input from man in the long term. Merely setting aside a reserve is no longer sufficient in most cases and managers will have to take an active role in manipulating the habitat, as well as coping with the consequences of genetic, demographic and environmental stochasticity (Soulé and Simberloff 1986, Shaffer 1987, Saunders et al. 1987).

The Noisy Scrub-bird Atrichornis clamosus survives in one small area on the south coast of Western Australia. This paper examines the species's habitat use and the implications that this has for management of the nature reserves where the bird occurs. 


\section{Historical background}

The Noisy Scrub-bird was first recorded in 1842 at Drakesbrook, $100 \mathrm{~km}$ south of Perth, Western Australia. Up to 1889, it was recorded in another five coastal localities between Perth and Albany. Despite numerous searches in the early decades of this century, the species was not recorded after 1889, and by the 1950 some ornithologists thought that it was extinct (Smith 1977). In December 1961, however, the Noisy Scrub-bird was rediscovered at Two Peoples Bay near Albany (Webster 1962) and this remains the only known locality where the bird has survived. The rediscovery started a long and at times acrimonious debate between conservationists and developers, who had been trying for some years to have the area where the rediscovery was made gazetted as a town site. The details of the dispute and its final resolution are given by Chatfield (in press). The Two Peoples Bay Nature Reserve $(4,637 \mathrm{ha}$ ) was created in 1967 for the conservation of fauna, primarily the Noisy Scrub-bird and two other rare birds, the Western Bristlebird Dasyornis longirostris and the Western Whipbird Psophodes nigrogularis. A detailed description of the natural history of the reserve is given in Hopkins and Smith (in press).

The Noisy Scrub-bird and the Rufous Scrub-bird A. rufescens of eastern Australia are part of an early radiation of Australian songbirds (Bock and Clench 1985, Sibley and Ahlquist 1985, Christidis and Schodde 1991) whose origin may go back as far as the Eocene, when much of southern Australia was covered by Nothofagus rainforest (Martin 1981), in which the ancestral scrub-birds are thought to have evolved. Climatic changes beginning in the Miocene resulted in the contraction and eventual extinction of Nothofagus in Western Australia. The Noisy Scrub-bird survived in isolated populations in wetter parts of the forest area of south-west Western Australia. It is clearly a relict species, but one that is evolutionarily robust, having withstood the environmental changes since the Miocene and in particular the dramatic climatic oscillations during the Pleistocene.

The decline of the Noisy Scrub-bird to near extinction in the 70 years after European settlement is thought to have been caused mainly by the changes in fire regimes caused by Europeans. Clearly, traditional Aboriginal burning practices which involved regular burning on a small scale, resulting in a mosaic pattern, were compatible with the survival of the species. Within 50 years of the arrival of Europeans, these practices had virtually ceased and were replaced by one with regular and extensive burning of heaths and shrublands every two to three years to provide feed for stock; or infrequent but intense, mainly accidental fires in woodlands and forests (Smith 1977, 1985c).

The survival of the Noisy Scrub-bird at Two Peoples Bay can be attributed to the topography of the area. The combination of a hilly and rocky headland backed by lakes and sand-dunes made the area unsuitable for agricultural and pastoral activities. The stronghold of the species is on the hilly headland (Figure 1) which has a series of bare granite ridges that are perpendicular to the prevailing winds and which act as natural fire-breaks and prevent the entire area from being burnt at one time. The effectiveness of this system of natural fire-breaks is illustrated by aerial photographs taken in 1946, which show that none of the numerous small fires that had occurred in the preceding years had 


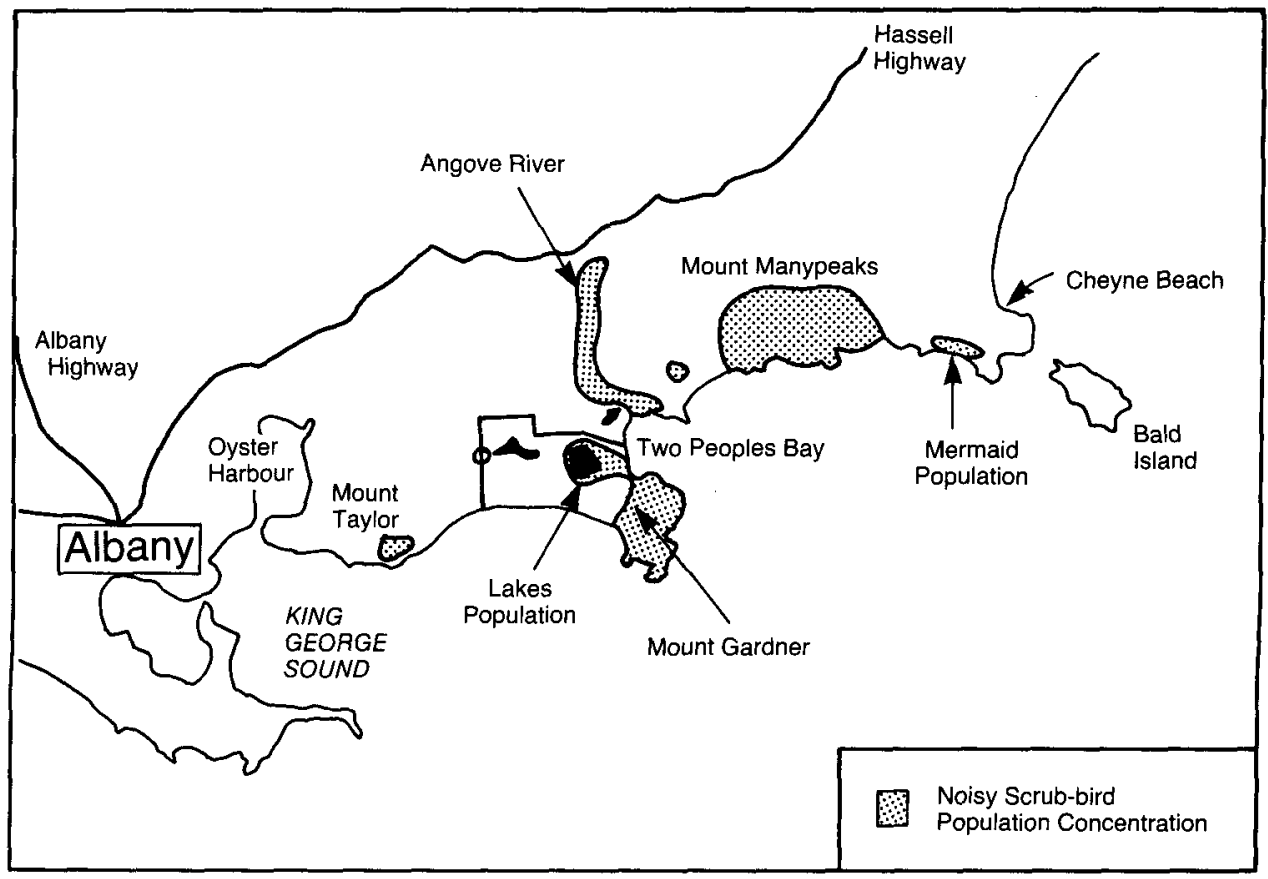

Figure 1. Region around Two Peoples Bay, showing areas with Noisy Scrub-birds (1992), native vegetation and farmlands.

burnt a significant percentage of the area. The occurrence of numerous small fires further enhanced the effectiveness of the natural fire-break system (Smith 1985a).

\section{Biology}

Noisy Scrub-birds are small (female $35 \mathrm{~g}$, male $52 \mathrm{~g}$ ), solidly built birds that are almost exclusively terrestrial; they use their limited flying ability mainly to move from shrub to shrub without having to visit the ground.

The males are territorial, defending their territories with a loud song which they sing throughout the year, but most frequently during the breeding season. Territories range in size from 4 to 9 ha (mean $6 \mathrm{ha}$ ), within which males spend $80 \%$ of their time in a core area of about 1-2 ha, which is used throughout the year and does not change from year to year. Core areas are dispersed and there is little or no overlap in territories. Since 1975 an increasing number of territories have had one or two subdominant adult males in addition to the dominant male. Little is known about the area used by the females; limited data suggest that they also use a small area centred around their nest, which is usually located on the periphery or outside the core area of the male's territory. The birds are mainly insectivorous, but females may occasionally feed their nestlings small frogs or lizards (Smith and Calver 1984).

The period from the start of nest building to the last nestlings in the population leaving the nest may extend from May to November, but more 
commonly ranges from June to October. Egg-laying begins in late May and ends in early October, with a peak in late June. Females alone build the nest, incubate the single egg and feed the nestling. The domed nest is built in a clump of rushes (Lepidosperma spp.) or dense shrub, usually about $0.2 \mathrm{~m}$ above the ground. The nesting period of the Noisy Scrub-bird is prolonged; the egg is incubated for $36-38$ days and the nestling fledges 3-4 weeks after hatching. It stays with its mother for about three months, probably until it has finished its post-fledging moult (Smith et al. 1983).

Only one female breeds within a male's territory. A male may breed with a younger female on the edge of his territory, and males have been recorded breeding with females in adjacent territories, after the resident male died. Females breed in their first year but males are not sexually mature until their third year.

A census of the population of Noisy Scrub-birds has been conducted annually since 1970 using the number of singing males as the population index. The number of males increased from 45 in 1970 to 189 in 1994 (Danks et al. 1995). Initially, the population was confined to the headland (Figure 1). In 1979 the first males were found on the edge of Lake Gardner and in the following years this subpopulation expanded throughout the area between the lakes, reaching a maximum of 64 in 1987. Thereafter, there has been a decline for unknown reasons, with only 1o males being recorded in 1994 (Danks et al. 1995).

Other aspects of the biology have been given in Smith (1976, 1978, 1985a), Smith and Robinson (1976) and Smith and Forrester (1981).

\section{Habitat}

The descriptions of habitat by the early and recent observers of these same areas suggest that the Noisy Scrub-bird was confined to the wetter areas of the forest dominated by marri Eucalyptus calophylla and jarrah E. marginata in the south-west of Western Australia (Beard 1981). Within this broad zone the preferred habitat appears to have been the ecotone between swamp and forest. The first Noisy Scrub-bird rediscovered in 1961 was in similar habitat.

Noisy Scrub-bird habitat may be divided broadly into nesting and feeding areas. Nesting occurs in the wetter areas where there is a dense ground cover of sedges (mostly Lepidosperma spp.) and/or small shrubs which provide nest sites, nest material and cover. Above this, there may be an open middle stratum of taller shrubs with the taller trees forming an open or closed canopy. Light intensity at ground level in these areas is low. Feeding areas are on the uphill side of a nesting area where it is drier and the ground cover is less dense; an increase in the middle and upper strata maintains a low light intensity. Here there is a dense litter layer which is the main feeding area for the species.

During the first census of the Noisy Scrub-bird in 1970, 34 of the 45 territories were located in low eucalypt forest, which is confined to the drainage system. In the steep V-shaped gullies draining to the sea, the functional equivalent of the ecotone between forest and swamp occurs as a narrow band of dense sedges and shrubs $2-5 \mathrm{~m}$ on either side of the creek bed. In the broader flat-floored valleys that drain inland, suitable feeding and breeding areas form a small-scale mosaic within the forest belt. In the narrower drainage lines nesting habitat 
may be confined to the sharp ecotone between low forest or thicket and the adjacent heath.

In the area around Lake Gardner and in the area between Lake Gardner and Lake Moates (Figure 1), the preferred habitat is Agonis spp. and Banksia littoralis forest and low forest with associated sedge and shrub communities. In this area, these vegetation associations are found in a narrow belt around the lakes and in the swales between the sand-dunes between the lakes. As with the flat-bottomed valleys on the headland, feeding and breeding habitats form a mosaic within the associations (Smith in press).

\section{Habitat use}

The changes in habitat use by the Noisy Scrub-bird from 1970 to 1983 were examined by Smith $(1985 \mathrm{~b})$. The vegetation in the core areas of all territories recorded since 1970 were classified into four structural categories: heath - dense shrub community up to $1 \mathrm{~m}$ in height and floristically diverse; thicket - dense, floristically diverse shrub formation with two strata up to $3 \mathrm{~m}$ tall; low forest A - dense formation with three strata up to $5 \mathrm{~m}$ tall with Eucalyptus spp., Agonis spp. or Hakea elliptica as dominants; low forest B - dense formation up to three strata taller than $5 \mathrm{~m}$, with Eucalyptus spp. and Agonis spp. as dominants. Breeding data and qualitative estimates of nesting potential and food resources were used to rank these formations on increasing suitability for Noisy Scrub-birds: heath, thicket, low forest A and low forest $B$.

In 1970, the percentages of territories $(n=45)$ in heath, thicket, low forest $A$ and low forest B were $0,7,51$ and 42 respectively. In 1983 the percentages for the population $(n=120$ ) on the headland (see Figure 1) were $4,19,53$ and 24 respectively. Between 1970 and 1983 the numbers of new territories established in these habitat categories were 5, 20, 41 and 9 respectively. All territories established in the area of the lakes were in low forest B. On the headland, low forest $B$ is confined to the valleys and its area is limited. The growing population has used increasingly lower-ranked habitats.

After 1983, the population continued to grow and the trends in habitat use noted above became more apparent. In 1988, the vegetation in all known territories was classified again, this time using the vegetation associations described by Hopkins et al. (in press). At 161 sites the vegetation could be assigned to one association, but at 70 sites the vegetation was a mosaic of two to three associations. These associations comprised nine dominated by trees, one by mallee, nine by shrubs and one by sedges. To reduce the complexity, the data were grouped into five classes (Table 1) in descending order of suitability for Noisy Scrub-birds. Sites with more than one association were assigned to the most extensive association at the site.

The number of sites occupied in each class from 1970 to 1988 are shown in Figure 2. With one exception, Agonis forest only provides habitat in the lakes area. After 1977 the number of sites in Agonis forest increased rapidly up to 1987, as Noisy Scrub-birds rapidly colonized the unoccupied habitat. The start of the decline in this subpopulation occurred in 1988 , for no apparent reason. There was no evidence of disease, food shortages or predation (A. H. Burbidge in litt. 1989), and no difference in the habitat between those territories that 
Table 1. Classification of territorial sites and the number of sites in each category.

$\begin{array}{llr}A & \text { Low Eucalypt Forest } & 65 \\ B & \text { Agonis Forest/Low Forest } & 66 \\ C & \text { Thicket: tall } & 50 \\ D & \text { Thicket: low } & 40 \\ E & \text { Heath } & 10 \\ \text { TOTAL } & 231\end{array}$

The vegetation associations of Hopkins et al. (in press) included in each class are as follows: $A$. Mixed low forest A, mixed Jarrah/Marri/Bullich low forest A, Allocasuarina fraseriana forest A/low woodland, gully mixed dense low forest A. B. Agonis juniperina forest/dense forest, Agonis juniperina low forest/scrub/thicket, Agonis juniperina dense low forest, Banksia littoralis low woodland A/open low forest, Agonis flexuosa low forest A/low woodland. C. and D. Mixed mallee shrublands, Mt. Gardner thicket, gully thicket, sand dune thicket/scrub, Phebalium thicket/scrub, swamp margin thicket. E. Isthmus mixed dense low heath, Peninsular mixed dense low heath, wet heath.

became vacant and those that did not, nor in time since the sites were first occupied. The reasons for the continuing decline are unknown.

The number of territories in low eucalypt forest increased up to 1979, then levelled off, suggesting that most of this habitat was occupied.

Thicket associations have been placed in two classes: those taller than $3 \mathrm{~m}$ and those less than $3 \mathrm{~m}$. The difference between the two classes relates mainly to the presence in tall thicket of patches of Eucalyptus spp. or Hakea elliptica which provide better habitat than those sites without patches of these species. Territories in both tall and low thicket increased slowly up to 1977. Thereafter

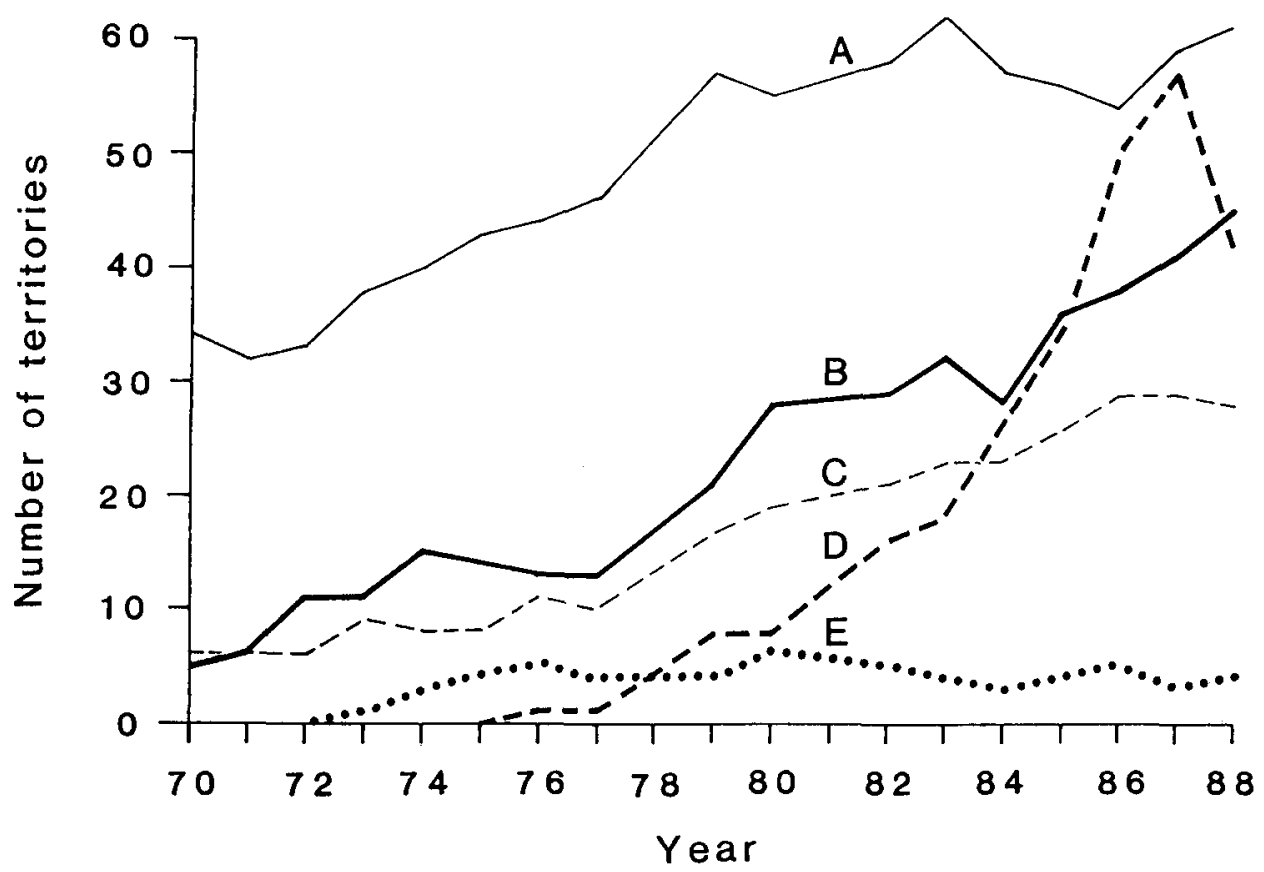

Figure 2. Number territories in each vegetation class (see Table 1) from 1970 to 1988 . A, low eucalypt forest; B, tall thicket; C, low thicket; D, Agonis forest; E, heath. 
the number of territories in tall thicket increased rapidly, while those in low thicket increased more slowly and had levelled out by 1986. It is not known whether this was because this habitat was fully used or whether there were insufficient birds. However, the rapid replacement of territorial males removed for translocation suggested that there were sufficient males to occupy any suitable unoccupied habitat.

The first territory in heath was recorded in 1973 and the number had increased to five by 1976; thereafter the number of territories fluctuated between three and six.

The changes in habitat use since 1970 indicate a hierarchy of habitat preferences similar to that proposed by Fretwell and Lucas (1970) and demonstrated by $\mathrm{O}^{\prime}$ Connor (1986). However, in this case the occupation of the ranked habitats is not linear. Part of this may be because the habitat classification is relatively crude. Also, it may pay birds to settle in the first suitable habitat they find after dispersing, rather than run the risk of prolonged searching for the preferred habitat.

There is no evidence of breeding in territories located in heath. If it does occur, it would be a rare event. Heath is probably best considered a survival (non-breeding) habitat. Eucalypt and Agonis forest are the preferred habitats and data from territories in eucalypt forest showed that breeding occurred every year. Low and tall thicket habitats are intermediate in suitability and breeding activity in them is irregular (G.T.S. unpubl. data).

Another index of habitat suitability is the year-to-year turnover rates of territories in the various habitat classes. Turnover $=100$ (number of new territories at $t_{2}+$ number of territories present at $t_{1}$, but not at $t_{2} /$ number of territories at $t_{1}+$ number of territories at $t_{2}$ ).

The mean annual turnover rates ( \pm standard deviation) for eucalypt forest, tall thicket, low thicket and heath were $5.3 \pm 2.36,12.9 \pm 7.16,20.9 \pm 15.21$ and $29.3 \pm 27.17$ respectively. The mean turnover rate and variability increases from the most suitable to the least suitable habitat. The high turnover rate in Agonis forest $(22.4 \pm 4.99)$ probably reflected the rapidly increasing population rather than any instability in the use of sites.

The use of turnover rate to rank habitat suitability implies differences in survival between the habitats. However, interpretation can be confounded in a population with a high reproductive rate where any vacancies are filled quickly. As a population approaches the carrying capacity of an area, apparent turnover rates should decline; there is some evidence for this in the Noisy Scrub-bird.

\section{Vegetation change}

The association of plant species at a particular site is controlled primarily by the edaphic and moisture conditions, and is modified by the fire regime, which will also influence the relative abundance of plants and the structure of the vegetation association. Over the last 20 years there have been considerable changes in the vegetation at Two Peoples Bay (Hopkins and Smith in press). The continuing growth and development of shrub- and tree-dominated associations has been reflected in an increase in height and canopy cover. These changes have been most noticeable in the area between the lakes, which was 
burnt last in 1970. The regeneration and growth of the Agonis and Banksia woodlands and forests and associated shrub and sedge communities has allowed the rapid colonization of the area by the Noisy Scrub-birds since 1979 .

Considerable changes have occurred also in the thicket associations, where the increase in height and canopy cover has been accompanied by the growth of a subdominant shrub and sedge layer. Also, the growth of patches of thicket with a dense canopy, with the resultant reduction in light intensity and changed moisture regime, has in turn led to the development of a dense border of shrubs and sedges with more open areas towards the centres of the patches. Such areas provide a favourable mosaic of habitat patches for Noisy Scrub-birds. The increase in the number of territories located in thicket associations reflects not only the occupation of unused sites by the expanding population, but also the increase in the total number of suitable sites due to the growth of the vegetation.

Changes in eucalypt forest are more subtle. Area and height have not changed significantly, but there have been periodic changes in the canopy cover because of windfalls and the death of trees. These small changes appear to lead to cyclic changes in the ground cover in small areas $\left(100 \mathrm{~m}^{2}\right)$, which are going through a process of growth and decay in the shrubs and sedges at different times, so that there are always some areas suitable for the Noisy Scrub-bird. The time-scale over which these changes are taking place is unknown, but some observations suggest that it may be of the order of 30 or more years.

\section{Habitat disturbance}

The major habitat disturbance at Two Peoples Bay has been fire. Prior to the arrival of Europeans, the area would have been subjected to Aboriginal burning practices similar to those at Albany (Smith 1985a). Later, fires caused by Europeans would have affected the area but were not documented. The earliest record of fire is on the 1946 aerial photographs which show that there had been numerous small fires on the headland with one larger fire on the isthmus. Later aerial photographs and eye-witness accounts indicate that more extensive fires have occurred at some time over most of the reserve.

The Noisy Scrub-bird, like many other small passerines, appears to be able to escape from fire (e.g. Rowley and Brooker 1987). H. O. Webster (verbally) found that five males survived an intense summer fire in 1962 but, unlike Malurus splendens (Rowley and Brooker 1987), either did not survive or did not remain in their territories beyond the following winter.

The regeneration after large fires in 1962 and 1964 allowed some data to be obtained on the time required for the vegetation to regenerate to a stage suitable for Noisy Scrub-birds. For eight sites affected by these fires, the periods range from four to 10 years. Regeneration and subsequent recolonization was fastest in those wet gullies with low eucalypt forest, where only the understorey plants were completely burnt. When breeding in those territories first took place after the fire is uncertain, but indirect evidence in two sites suggests that it was probably four to six years. The slowest regeneration and recolonization (10 years) occurred in swales in old sand-dunes where the vegetation had been completely destroyed. The establishment of territories in adjacent unburnt areas 
suggests that a lack of birds was not the reason for the long interval between the fire and recolonization.

The vegetation around Lake Gardner and between the lakes was burnt in 1970. By 1976, at least some areas had suitable Noisy Scrub-bird habitat, even though the birds did not start to recolonize the area until 1979. The time-scale for regeneration appears to be similar to that on the headland. In the wet areas regeneration may take less than six years. In the drier sand-dunes separating the lakes, habitat regeneration may take at least to years.

At the other end of the scale, how long will an area remain suitable for Noisy Scrub-birds following recolonization after a fire? Examination of the 1946 aerial photographs indicated that the sites of nine territories in low eucalypt forest showed no sign of having been burnt then, and there is no evidence to suggest that they have been burnt subsequently. Six of these territories have been used continuously since at least 1968, while the other three have been used intermittently during this period (Smith 1985c). The length of time thicket associations remain suitable for Noisy Scrub-birds after recolonization is uncertain. Two sites burnt in the 1962 fire have been occupied continuously since they were reoccupied, and another seven sites are still being used after being burnt in the years preceding the 1946 aerial photography. These sites may have been burnt after 1946, but definitely not since around 1960. Three territories which had not been burnt since 1946 and in which Hakea elliptica was a dominant were found to have lost most of their large $H$. elliptica in 1994, resulting in the abandonment of one territory (the other two having sufficient adjacent habitat). The death of these plants may have been due to old age or from Phytophthora cinnamomi infection.

These data, while imprecise, provide some guidelines on the relationship between fire frequency and habitat suitability. Fire frequencies of less than 1o years, depending on habitat, will be deleterious to the population. The longer the habitat is protected from fire the better, because it will allow the full carrying capacity of the reserve to be realized. At this stage the upper time limit is unknown, but may exceed 70 or more years for low eucalypt forest, less for thicket associations. There are no data on the duration that Agonis forest will remain suitable for Noisy Scrub-bird following recolonization after fire.

Another factor that has affected the vegetation on the reserve is the soil-borne fungus $P$. cinnamomi. In a review of the effect of this pathogen on the vegetation on the reserve, Hart (in press) found that infections occurred over all the reserve and were spreading at a rate of at least one metre per year. The impact of the infections was most severe in Banksia communities, moderate in jarrah forests and high in the shrub and heath communities of the headland. The impact appears to be permanent, because the vegetation does not recover even after decades.

The date the original infection reached the reserve is unknown, but probably was well before 1940 . The peak of activity for $P$. cinnamomi occurred many years ago in most areas of the reserve. In areas with old and well established infections, all the susceptible species have been killed and the vegetation looks healthy. While many species, especially those in the Proteaceae, Papilionaceae and Epacridaceae are susceptible, the sedges (Cyperaceae and Restionaceae) are 
Table 2. Effective population size, $N_{\mathrm{e}}$, for 1987 and 1988 using the four sets of assumptions given in the text.

\begin{tabular}{ccc}
\hline Assumption & 1987 & 1988 \\
\hline 1 & 472 & 429 \\
2 & 432 & 395 \\
3 & 382 & 345 \\
4 & 298 & 264 \\
\hline
\end{tabular}

not. This is important for Noisy Scrub-birds because the sedges are the main nest sites and provide the main nest building material. The fact that the Noisy Scrub-bird population has continued to grow during the last 20 years, in the presence of chronic $P$. cinnamomi infections, suggests that whatever effect $P$. cinnamomi may have had on the vegetation, it appears to have had little impact on the habitat requirements of the Noisy Scrub-bird.

\section{Demography}

The important population statistic for conservation is not the total population but the reproductively active part of the population, i.e. the effective population size, represented by the formula $N_{\mathrm{e}}=4 N_{\mathrm{f}} N_{\mathrm{m}} /\left(N_{\mathrm{f}}+N_{\mathrm{m}}\right)$, where $N_{\mathrm{f}}$ and $N_{\mathrm{m}}$ are the number of breeding females and males respectively (Ewens et al. 1987).

Neither $N_{\mathrm{f}}$ nor $N_{\mathrm{m}}$ is known for the Noisy Scrub-bird. However, a range of these values can be calculated by using the number of territories in each habitat category and by assuming that the percentage of birds breeding and the probability of there being an extra breeding female in a territory (see section on biology) will increase with increasing suitability of the habitat. By making a series of (mutually exclusive) assumptions, a range of values of $N_{\mathrm{e}}$ can be calculated that can be used when considering management strategies. The assumptions are that all territories:

(1) have one breeding pair and $50 \%$ of territories have an extra breeding female;

(2) (except those in heath) have one breeding pair and 50\% of territories in low forest have one extra breeding female;

(3) in low forest and tall thicket have one breeding pair, 50\% of territories in low thicket have one breeding pair, and $25 \%$ of territories in low forest have one extra breeding female;

(4) in low forest have one breeding pair, while $50 \%$ of territories in tall thicket and $25 \%$ of territories in low thicket have one breeding pair (see above for descriptions of habitat types).

The assumptions range from an obvious overestimate of the breeding potential of the population (I) to an underestimate (4). Assumptions (2) and (3) probably span the real reproductive potential. The values of $N_{\mathrm{e}}$ were calculated from the population data for 1987 and 1988 and the values are given in Table 2. The value for the two years range from 298 to 472 and 264 to 429 respectively.

An effective population size $\left(N_{e}\right)$ of 500 is sometimes accepted as the minimum required to maintain genetic variation (see discussions in Lande 1988, Simberloff 1988). The data given above suggest that even with the most favourable assump- 
tions the present $N_{\mathrm{e}}$ values for the Noisy Scrub-bird fall below that figure. To reach an $N_{e}$ of 500 would require, on the above assumptions, between 208 and 311 territories.

\section{Habitat management}

After the rediscovery of the Noisy Scrub-bird, fire was identified as the most potent threat to its continued existence. The first management plan (Anon. 1971) emphasized the need to preclude fire from the reserve, and as a result boundary and internal fire-breaks were established and a resident ranger was appointed to oversee the reserve.

In 1976 a strategic fuel-reduced zone was established in heath across the isthmus. This zone consisted of two lines of six c.12 ha blocks, two of which have been burnt every year. The aim was to produce a zone with low fuel that would impede any fire burning towards the headland, but at the same time provide adequate corridors in older vegetation that would allow the movement of fauna (Hopkins 1985).

The policy of fire exclusion has been successful so far: the only large fire on the reserve since 1970 did not burn any Noisy Scrub-bird habitat. The absence of fire has allowed vegetation growth to proceed uninterrupted, leading to both the development of new areas of habitat and the improvement of existing marginal habitat.

These changes have been beneficial not only for the Noisy Scrub-bird but also for the Western Bristlebird and Western Whipbird, whose preferred habitats are heath and thicket/heath (Smith 1987, 1991). Both species have increased their populations and ranges within the reserve. However, one undesirable consequence of the growth of the vegetation has been the decline in the potential effectiveness of the outcrop areas as fire-breaks. Not only has the effective width of these areas been reduced, but the increased fuel load has increased the chances of a fire jumping the barrier. Also, on some outcrops dense lines of shrubs have developed in cracks across the outcrop. Increasing the effectiveness of these outcrops as fire barriers is a large but not impossible task for management.

Management of the reserve for the Noisy Scrub-bird has to take into account two other considerations: public access and other species considered to be of conservation interest. Two Peoples Bay has been a popular recreational area for many years (Chatfield in press) and, when the reserve was created, provision was made for public vehicle access to the beaches (Two Peoples Bay and Little Beach) and to the wave-cut platform at Sinker Reef. Access to other parts of the reserve was restricted to walking tracks except for the northern half of the headland, which was declared a research area and closed to the public. At Two Peoples Bay beach a picnic area with information board and nature trail was established and the picnic area was later provided with free gas barbecues to reduce the risk of fire. The beaches are the most popular areas and attract about 30,000 people a year. This high level of use raises questions about public safety, especially from wildfires. The continuing growth of the vegetation in the reserve increases the chances of a severe wildfire, and eventually control fires may have to be used to reduce this risk. This question is at present being addressed in a revision of the management plan for the reserve. 
Twenty-two vertebrate species on the reserve have been listed as being of special conservation interest (Smith and Moore in press). However, only four Noisy Scrub-bird, Western Bristlebird, Western Whipbird and an opossum (western ringtail Pseudocheirus occidentalis - are considered to be rare or likely to become extinct by the Western Australian Department of Conservation and Land Management. Managing scrub-bird habitat is unlikely to affect the whipbird, because of the overlap in habitat in requirements, or the bristlebird, which only uses heath. The ringtail lives in low eucalypt forest and possibly Agonis forest; detailed habitat requirements will need to be ascertained before any habitat management programme is started.

Examination of the habitats occupied by the Noisy Scrub-bird suggests its tolerance is reasonably wide, but that within this range its preferred habitat is fairly specific in terms of structure and available food resources. Habitat quality is affected by both the available area of preferred habitat and the degree to which the habitat conforms to the preferred characteristics for nesting and foraging.

The extent to which a site departs from the preferred habitat may be expressed in terms of increased turnover rates or reduced frequency of breeding. In considering management options, attention should be given not only to the size of the population but also to the numbers occupying the various habitats, especially eucalypt and Agonis forest, and to a lesser extent to tall thickets, because these are the main breeding habitats. To determine when management will be required, constant monitoring of the population, turnover rates and habitats will be necessary.

It may be argued that management intervention should begin before its need becomes obvious from the decline in the population. Such a policy could involve relatively infrequent but regular rotational burning of small areas within the two scrub-bird populations so that all areas would be well within the productive age-span of the habitat. Given the data from the fire history, the optimal fire frequency would be about fifty years for forest habitat, and probably less for thicket habitats. However, such a policy should take into account the effects of periodic reductions in the population.

If an $N_{\mathrm{e}}$ value of 500 is a reasonable management aim, then as noted above there would need to be between 208 and 311 territories on the reserve. Only in 1990 did the population reach this lower limit, but the majority of new territories have been established in thicket habitat. There is little scope for further increases in low eucalypt forest and tall thicket on the headland. It is uncertain if future increases in the population will give an $N_{\mathrm{e}}$ of 500 .

In order to achieve and preferably to better an $N_{\mathrm{e}}$ of 500 , it will be necessary to direct management activity towards ensuring that the population on the reserve and the growing population at Mt Manypeaks (minimum of 6o territories in 1991: A. Danks pers. comm.) have sufficient suitable habitat between them to facilitate gene-flow (Smith 1985b). In 1987 Noisy Scrub-birds were first located on the Angove River (Figure 1) and by 1990 10 territories had been established along the river and across to Boulder Hill. All birds were thought to have dispersed from Two Peoples Bay (Danks 1991, A. Danks pers. comm.). The ability of birds to disperse into this area, and the presence of suitable habitat between it and Mt Manypeaks, indicates that in future this small population may act as a link between the two areas. 
Birds have dispersed also to the Goodga River and further west to Mt Taylor, where a small number of birds were subsequently translocated (Danks 1991). This gives hope that in the future a regional population will develop, consisting of three large populations (one at Mt Manypeaks and two at Two Peoples Bay) plus three or more smaller subpopulations, all linked by corridors of suitable habitat. In 1990, 287 territories had been located in the region (A. Danks pers. comm.). Depending on the habitat used by these birds, the $N_{\mathrm{e}}$ target of 500 may at that stage have been reached; certainly the continued growth of the population will ensure that this target is achieved.

If the concept of a regional population is to be achieved, the corridors between the populations will need to be given formal standing and have to be managed. This will require the cooperation of the government agencies and private individuals who control the land. The most important management actions will be the need to control wildfires and eliminate grazing by stock. Also, damage by vehicle and human trampling will need to be controlled and hygiene measures implemented to prevent or reduce the spread of Phytophthora cinnamomi.

\section{Conclusions}

Examination of habitat use and the ranking of habitats according to breeding potential have identified low eucalypt and Agonis forests as the most important habitat for management consideration. Fire is not only the most dangerous potential disturbance but is also the only management technique that can be used in large areas to rejuvenate the vegetation. The present data indicate that management should aim for a fire frequency of about 50 years. The exclusion of fires poses problems for managers because it leads to an increasing risk of severe wildfires. This situation may result in political pressure being applied to allow more frequent fuel-reduction fires.

The important aspects of the management of Noisy Scrub-bird habitat are the identification of optimal habitat and how long it remains optimal. The widespread infections of $P$. cinnamomi have caused considerable changes in the vegetation. However, these changes do not appear at present to have had a significant effect on the habitat of the Noisy Scrub-bird, Western Whipbird or Western Bristlebird.

To ensure the long-term future of the Noisy Scrub-bird, a number of populations will need to be established. Burbidge et al. (1986) suggest a minimum of four. Ideally, these populations should be as large as possible. An effective population size of about 500 may be a reasonable initial management objective, given our limited knowledge of the species's reproductive biology and lack of data on its genetics. Although the translocation to Mt Manypeaks was successful, it is uncertain if the populations at Two Peoples Bay or Mt Manypeaks will ever have an effective population size of 500. However, the establishment of a small population in the Angove River area, together with two other small populations, indicates that an integrated regional population is possible. At present, the effective size of this population is unknown but is probably approaching 500. The development of such a metapopulation should provide advantages in stemming the effects of disasters such as result from disease, fire, etc., but may also enhance genetic diversity (Simberloff 1988). 
To ensure that the regional population becomes genetically integrated, the cooperation of the various landowners in the management of the areas with populations and the corridors between them is essential. It is essential that management be directed towards reducing the incidence of wildfire and ensuring that a wildfire in one area cannot spread to other areas of population. In the long term wildfire may be impossible to prevent, but if any such fires can be contained in a small area the effect on the regional population will be relatively small.

The growth of the population and increase in the distribution of the Noisy Scrub-bird over the last 20 years has made the future of the species more secure. Continued management of the region, especially the control of wildfires, together with further successful translocations, should ensure its long-term future.

\section{Postscript}

This paper is based on work carried out in 1988, with only a few minor updates since the first draft (1989). Full details of the changes in the populations are given in Danks et al. 1995. The management of the reserve is described in Two Peoples Bay Nature Reserve management plan 1995-2005, Western Australian Department of Conservation and Land Management, 1995.

\section{Acknowledgements}

I thank Mike Ellis, Les Moore, Dick Grayson, Ron Sokalowski, Graeme Folley and Alan Danks for their assistance over the last 19 years, Ian Rowley, Mike Brooker, Richard Hobbs, Jim Lynch, Angus Hopkins and Brian Bell for their comments on various drafts of the manuscript, Claire Taplin and Jean Rae for typing it and Perry de Rebeira for the illustrations.

\section{References}

Anon. (1971) Two Peoples Bay management plan. Swans 2: 52-53.

Beard, J. S. (1981) Vegetation survey of Western Australia. I Swan 1:1,000,00o vegetation series. The vegetation of the Swan area. Perth: University of Western Australia Press.

Bock, W. J. and Clench, M. H. (1985) Morphology of the Noisy Scrub-bird, Atrichornis clamosus (Passeriformes: Atrichornithidae): systematic relationships and summary. Rec. Austral. Mus. 37: 243-254.

Burbidge, A. A., Folley, G. L. and Smith, G. T. (1986) The Noisy Scrub-bird. Wildlife Management Program No. 2. Western Australian Department of Conservation and Land Management.

Chatfield, G. R. (in press) History and establishment of Two Peoples Bay Nature Reserve. In A. J. M. Hopkins and G. T. Smith, eds. The natural history of Two Peoples Bay Nature Reserve. CALM Science Supplement, Western Australian Department of Conservation and Land Management.

Christidis, L. and Schodde, R. (1991) Relationship of Australian Papuan songbirds protein evidence. Ibis 133: 277-285. 
Danks, A. (1991) The role of corridors in the management of an endangered species. Pp. 291-96 in D. A. Saunders and R. J. Hobbs, eds. Nature Conservation 2: the role of corridors. Sydney: Surrey Beatty and Sons.

Danks, A., Burbidge, A. A., Burbidge, A. H. and Smith, G. T. (1995) Noisy Scrub-bird recovery plan. Perth: Western Australian Department of Conservation and Land Management, Wildlife Management Program No. 12.

Ewens, W. J., Brockwell, P. J., Gani, J. M. and Resnick, S. I. (1987) Minimum viable population size in the presence of catastrophes. Pp.59-68 in M. E. Soulé, ed. Viable populations for conservation. Cambridge, U.K.: Cambridge University Press.

Fretwell, S. D. and Lucas, H. L. (1970) On territorial behaviour and other factors influencing habitat distribution in birds. 1. Theoretical development. Acta Biotheoretica 29: 16-36.

Hopkins, A. J. M. (1985) Planning the use of fire on conservation lands in South-western Australia. Pp.203-208 in J. Ford, ed. Fire ecology and management in Western Australian ecosystems. Perth: WAIT Environmental Studies Group. Report No. 14.

Hopkins, A. J. M. and Smith, G. T., eds. (in press) The natural history of Two Peoples Bay Nature Reserve. CALM Science Supplement, Western Australian Department of Conservation and Land Management.

Hopkins, A. J. M., Williams, A. A. E. and Brown, J. M. (in press) The vegetation. In A. J. M. Hopkins and G. T. Smith, eds. The natural history of Two Peoples Bay Nature Reserve. CALM Science Supplement, Western Australian Department of Conservation and Land Management.

Lande, R. (1988) Genetics and demography in biological conservation. Science 241: 14551460.

Martin, H. A. (1981) The tertiary flora. Pp.393-406 in A. Keast, ed. Ecological biogeography of Australia. The Hague: W. Junk.

O'Connor, R. J. (1986) Dynamical aspects of avian habitat use. Pp.235-237 in J. Verner, M. L. Morrison, and C. J. Ralph, eds. Wildlife 2000. Madison: University of Wisconsin Press.

Rowley, I. and Brooker, M. (1987) The response of a small insectivorous bird to fire in heathlands. Pp.211-218 in D. A. Saunders, G. W. Arnold, A. A. Burbidge and A. J. M. Hopkins, eds. Nature conservation: the role of remnants of native vegetation. Sydney: Surrey Beatty and Sons.

Saunders, D. A., Arnold, G. W., Burbidge, A. A. and Hopkins, A. J. M., eds. (1987) Nature conservation: the role of remnants of native vegetation. Sydney: Surrey Beatty and Sons.

Shaffer, M. (1987) Minimum viable populations: coping with uncertainty. Pp.69-86 in M. E. Soulé, ed. Viable populations for conservation. Cambridge, U.K.: Cambridge University Press.

Sibley, C. G. and Ahlquist, J. E. (1985) The phylogeny and classification of the AustraloPapuan passerine birds. Emu 85: 1-14.

Simberloff, D. (1988) The contribution of population and community biology to conservation science. Ann. Rev. Ecol. Syst. 19: 473-511.

Smith, G. T. (1976) Ecological and behavioural comparisons between the Atrichornithidae and Menuridae. Proc. XVI Internatn. Orn. Congr.: 125-136.

Smith, G. T. (1977) The effect of environmental change on six rare birds. Emu 77: 173179.

Smith, G. T. (1978) The Noisy Scrub-bird. Pp. 117-121 in M. J. Tyler, ed. The status of endangered Australasian wildlife. The Royal Society of South Australia, Adelaide.

Smith, G. T. (1985a) The Noisy Scrub-bird (Atrichornis clamosus), does its past suggest a future? Pp. 301-308 in A. Keast, H. Recher, H. Ford and D. A. Saunders, eds. Birds of the Eucalypt forests and woodlands: ecology, conservation and management. Sydney: Surrey Beatty and Sons. 
Smith, G. T. (1985b) Population and habitat selection of the Noisy Scrub-bird (Atrichornis clamosus), 1962 to 1983 . Austral. Wildl. Res. 12: 479-85.

Smith, G. T. (1985c) Fire effects on populations of the Noisy Scrub-bird (Atrichornis clamosus), Western Bristlebird (Dasyornis longirostris) and Western Whipbird (Psophodes nigrogularis). Pp.95-102 in J. R. Ford, ed. Fire ecology and management of ecosystems in Western Australia. Environmental Studies Group. WAIT. Bull. 13.

Smith, G. T. (1987) Observations on the biology of the Western Bristlebird Dasyornis longirostris. Emu 87: 111-118.

Smith, G. T. (1991) Ecology of the Western Whipbird Psophodes nigrogularis in Western Australia. Emu 91: 145-157.

Smith, G. T. (in press) Habitat of the Noisy Scrub-bird Atrichornis clamosus, Western Whipbird Psophodes nigrogularis and Western Bristlebird Dasyornis longirostris. In A. J. M. Hopkins and G. T. Smith, eds. The natural history of Two Peoples Bay Nature Reserve. Research Bulletin, Western Australian Department of Conservation and Land Management.

Smith, G. T. and Calver, M. C. (1984) The diet of the nestling Noisy Scrub-bird. Austral. Wildl. Res. 11: 553-558.

Smith, G. T. and Forrester, R. I. (1981) The status of the Noisy Scrub-bird (Atrichornis clamosus). Biol. Conserv. 19: 239-54.

Smith, G. T. and Moore, L. A. (in press) Vertebrate fauna. In A. J. M. Hopkins and G. T. Smith, eds. The natural history of Two Peoples Bay Nature Reserve. Research Bulletin, Western Australian Department of Conservation and Land Management.

Smith, G. T., Nicholls, C. A., Moore, L. A. and Davis, H. (1983) The results of a breeding programme for the Noisy Scrub-bird (Atrichornis clamosus) in captivity. West. Austral. Nat. 15: 151-157.

Smith, G. T. and Robinson, F. N. (1976) The Noisy Scrub-bird, an interim report. Emu 76: $37-43$.

Soulé, M. E. and Simberloff, D. (1986) What do genetics and ecology tell us about the design of nature reserves? Biol. Conserv. 35: 19-40.

Webster, H. O. (1962) Rediscovery of the Noisy Scrub-bird. West. Austral. Nat. 8: 57-9.

G. T. SMITH

CSIRO Division of Wildlife \& Ecology, LMB No. 4, Midland, WA 6056, Australia 